\title{
Torture, Who Knew? \\ An Analysis of the FBI and Department of Defense Reactions to Harsh Interrogation Methods at Guantánamo
}

\author{
Mark Denbeaux* \\ Joshua Denbeaux \\ David Gratz \\ Megan Sassaman \\ Daniel Mann \\ Matthew Darby \\ Michael Ricciardelli
}

I witnessed SGT [REDACTED] placing lotion in her hand and touching a detainee. She was whispering in the detainee's ear as her hand traveled to the detainee's lap. I didn't see her hands (because her body obstructed my view) touch the detainee's groin, but the detainee started to grimace in pain. Later, a Marine told me that SGT [REDACTED] bent the detainee's thumbs back. He went on to say that "if you think that this is bad, she has done worse."

[The Government's investigation] found no evidence of torture or inhumane treatment at JTF-GTMO. ${ }^{2}$

* Professor, Seton Hall University School of Law, and Director, Seton Hall University School of Law Center for Policy and Research. The Report also benefited from the research and contributions of Grace Byrd, Adam Deutsch, Douglas Eadie, Jennifer Ellick, Deborah Fish, Christopher Fox, Jillian Gautier, Gabrielle Hughes, Daniel Lorenzo, Mark Muoio, Michael Patterson, Courtney Ray, Paul Taylor, and Lauren Winchester.

Partner, Denbeaux \& Denbeaux. Co-authors Professors Mark Denbeaux and Joshua Denbeaux represent two Guantánamo detainees.

1 Letter from T.J. Harrington, Deputy Assistant Dir., Fed. Bureau of Investigation, to Donald J. Ryder, Major Gen., U.S. Army (July 14, 2004) [hereinafter Harrington Letter] (alterations in original), available at http://www.aclu.org/torturefoia/released/FBI_4622_4624.pdf.

2 U.S. DeP'T OF Def., ARmy Regulation 15-6: Final Report, InVESTigation into FBi Allegations of Detainee Abuse at Guantánamo Bay, Cuba Detention Facility 


\section{Methodology}

This Report explains how senior officials at the Federal Bureau of Investigation (FBI) and the Department of Defense (DOD) responded to the numerous reports filed by FBI agents in response to improper techniques used by DOD interrogators at Guantánamo Bay. The present Report does not attempt to present a complete picture of all interrogation techniques actually used at Guantánamo. Rather, this Report presents only those techniques described by FBI field agents in their own reports. The reviewed agents' reports are from three sources: (1) unsolicited reports received by senior FBI officials prior to 2004, (2) solicited reports sent to senior FBI officials in 2004 pursuant to an FBI directive, and (3) notes compiled from the Schmidt-Furlow investigation of detainee abuse at Guantánamo ${ }^{3}$ and labeled in the appendix to the investigation report- "Investigation into FBI Allegations of Detainee Abuse at Guantanamo Bay, Cuba Detention Facility" (the "Schmidt Report")—as "Enclosures."

Therefore, this Report relies entirely upon statements made by U.S. government agents (whether FBI agents, DOD employees, or civilian contractors serving as employees and agents of the DOD). All of the complaints cited in this Report, to the extent it is possible to discern them, describe the actions of DOD interrogators as witnessed by FBI agents who were present. ${ }^{5}$ The present Report does not address any allegations that have been raised only by detainees. ${ }^{6}$

Thus, this Report does not attempt to document all detainee abuse during interrogation. (That information has been published by others with greater access to unredacted reports.) Rather, this Report

\footnotetext{
$1 \quad$ (2005) [hereinafter $\quad$ SCHMIDT $\quad$ REPORT], available at http:/ /www.defense.gov/news/Jul2005/d20050714report.pdf.

${ }^{3} I d$.

${ }^{4}$ U.S. DeP'T OF DEF., SChMidT-Furlow RePORT EnClosures (2005) [hereinafter ENCLOSURES], available at http://action.aclu.org/torturefoia/released/ 061906/Schmidt_FurlowEnclosures.pdf.

The documents that are relied upon in this Report represent only a small part of the approximately 100,000 documents released as a result of a Freedom of Information Act (FOIA) application by the American Civil Liberties Union (ACLU). See Documents Released Under FOIA, AM. Civ. LIBERTIES UNION, http://www.aclu.org/safefree/torture/torturefoia.html (last visited Sept. 28, 2011) [hereinafter FOIA Documents]. The identification of the documents crucial to this Report was, in large part, the result of the research and investigation conducted by Matthew Darby, Daniel Mann, and, above all, Megan Sassaman.

${ }^{5}$ This Report refers to military police conduct only when such conduct is at the behest of an interrogator.

${ }^{6}$ Most of the documents cited in this Report were obtained by the ACLU through FOIA litigation. See FOIA Documents, supra note 4. The United States government released a minority of the documents cited in this Report.
} 
shows what information FBI agents at Guantánamo recorded and sent up the chain of command to headquarters. From this information, it is possible to determine what FBI Headquarters and the DOD knew-and what they did-about detainee mistreatment during interrogations.

The documents analyzed in this Report were culled from over 100,000 pages of documents that have been produced as a result of FOIA litigation. ${ }^{7}$ While the majority of these documents describe conduct in Afghanistan and Iraq, this Report analyzes only those documents describing Defense Department interrogators' mistreatment of detainees at Guantánamo.

Most of these documents-which include both the solicited and unsolicited reports evaluated in this Report—consist primarily of emails sent from FBI agents to senior FBI officials. The government has heavily redacted these documents. In almost all cases, dates and names have been withheld; in many cases, substantive information has also been redacted. In fact, of the 251 solicited and unsolicited responses ultimately reviewed in this Report, more than $40 \%$ were so heavily redacted that more than half of the original document's content remains obscured. More than $15 \%$ of these documents contain full-page redactions or appear to be missing entire pages, and more than $25 \%$ refer to appendices that have not been released. Redacted documents are difficult to catalog without errors, but duplicative documents were eliminated from this Report's analysis to the greatest extent possible. Some documents were entirely redacted and are thus impossible to review; those are not reported here.

In contrast to the FBI agents' individual reports, the Schmidt Report addresses interrogators' conduct only generally. ${ }^{8}$ The present Report examines the Schmidt Report as it was presented to Congress, and it also considers the reports "Enclosures": a collection of notes and documents from Lieutenant General Randall M. Schmidt's investigation ${ }^{9}$ compiled for an unknown purpose and appended to the Schmidt Report without comment. The Enclosures consist primarily of summaries of interviews with FBI agents, Defense Department in-

${ }^{7}$ See id.

${ }^{8}$ See SCHMIDT REPORT, supra note 2.

9 See Memorandum from Bantz J. Craddock, Gen. U.S. Army, for Lieutenant Gen. Randall M. Schmidt, USAF (Dec. 29, 2004) [hereinafter Craddock Memo], in ENCLOSURES, supra note 4, at available at http://action.aclu.org/torturefoia/released/061906/ Schmidt_FurlowEnclosures.pdf. 
terrogators, and senior Defense Department officials. ${ }^{10}$ Also included among the Enclosures are interrogation logs and memoranda regarding torture allegations.

In spite of the Schmidt Report's ambiguity-and despite the government's heavy redactions of other documents relied upon by this Report-an analysis of publicly available data reveals a much greater breadth of alleged Defense Department misconduct than is addressed by the Schmidt Report, notwithstanding that General Schmidt was personally aware of (or could have easily discovered) all of the misconduct that is discussed in the present Report.

\section{THE EARLYYEARS: FBI REPORTS MistreATMENT OF DETAINEES BY DEPARTMENT OF DEFENSE INTERROGATORS}

Beginning in 2002, FBI agents witnessed conduct by DOD interrogators at Guantánamo that compelled several agents to document their complaints in reports to FBI administrators. These unsolicited complaints, which, the agents alleged, were met by Defense Department personnel with indifference, ${ }^{11}$ describe actions performed by Defense Department personnel that include beatings as well as exploitation of detainees' religious beliefs and sexuality. ${ }^{12}$ Other types of misconduct alleged in the FBI agents' unsolicited complaints include hoodings, ${ }^{13}$ denial of food and water, ${ }^{14}$ sleep deprivation, ${ }^{15}$

\footnotetext{
${ }^{10}$ ENCLOSURES, supra note 4.

11 See, e.g., U.S. DeP'T OF Def., Schmidt-Furlow Report, DefErred 3770 [hereinafter SCHMIDT-FURLOW DEFERRED, available http://www.aclu.org/torturefoia/legaldocuments/july_docs/(M)\%20SCHMIDTFURLOW\% 20DEFERRED.pdf ("We talked to him (Mr. [REDACTED]) several different times to let him know that we objected to the use of dogs and that we did not do business that way. It was an inappropriate measure. He told us that we ([REDACTED] and I) were guests and we should act accordingly." (alterations in original)).

12 See E-mail from [REDACTED] to [REDACTED] (July 31, [REDACTED], available at http:/ /action.aclu.org/torturefoia/released/022306/2600.pdf ("Last evening I went to observe an interview of [REDACTED] with [REDACTED]. The adjoining room, observable from the monitoring booth, was occupied by 2 DHS investigators showing a detainee homosexual porn movies and using a strobe light in the room. We moved our interview to a different room." (alterations in original)).

${ }^{13}$ E-mail from [REDACTED], Fed. Bureau of Investigation, to [REDACTED], Fed. Bureau of Investigation (May 5, 2004, 08:50 AM), available at http:/ /action.aclu.org/torturefoia/released/022306/2715.pdf

("Based on Rumsfeld's public statements, DOD is against hooding prisoners, threats of violence and techniques meant to humiliating detainees (there is a list I have seen). I know these techniques were approved at high levels w/in DOD and used on [REDACTED] and [REDACTED].”(alterations in original)).

${ }^{14}$ E-mail from [REDACTED], Fed. Bureau of Investigation, to [REDACTED], Fed. Bureau of Investigation (May 5, 2004, 11:04 AM), available at
} 
threats, ${ }^{16}$ wrapping detainees in Israeli flags, ${ }^{17}$ the use of dogs, ${ }^{18}$ strobe lights, ${ }^{19}$ loud noises, ${ }^{20}$ and extreme temperatures. ${ }^{21}$

The FBI agents' unsolicited complaints not only describe alleged misconduct by DOD interrogators, but also articulate specific reasons for concern with their interrogation tactics. One agent summarized the popular sentiment among agents as follows: "These tactics have produced no intelligence of a threat neutralization nature to date and CITF [Criminal Investigation Task Force] believes that [sic] techniques have destroyed any chance of prosecuting this detainee." ${ }^{22}$

http://www1.umn.edu/humanrts/OathBetrayed/FBI\%204985-4987.pdf ("During the 12 hours [REDACTED] was not permitted to eat, pray, or use the bathroom.").

${ }_{15}$ Memorandum from [REDACTED] to Wiley, Special Agent in Charge, [REDACTED] ([REDACTED]) [hereinafter Wiley Memo], available at http:/ /action.aclu.org/torturefoia/released/022306/2561.pdf.

${ }^{16}$ Memorandum from [REDACTED] to [REDACTED] ([REDACTED]) [hereinafter FBI 4645-4647], available at http://www.aclu.org/files/torturefoia/released/FBI_4645_4647.pdf (“Agents have seen documentary evidence that a detainee was told that his family had been taken into custody and would be moved to Morocco for interrogation if he did not begin to talk.").

${ }^{17}$ E-mail from [REDACTED] to [REDACTED] (July 31, [REDACTED], 12:53 $\mathrm{PM})$, available at http://action.aclu.org/torturefoia/released/022306/2600.pdf [hereinafter Detainee 2600] ("[U]sing tactics as described above and others [such as]wrapping in Israeli flag ....”)).

${ }_{18}$ FBI 4645-4647, supra note 16 ("Agents [were] aware of detainees being threatened (either in person or aurally) by dogs.").

${ }^{19}$ Detainee 2600, supra note 17 (noting that agent observed two DHS investigators using a strobe light).

${ }^{20}$ Wiley Memo, supra note 15 ("BAU personnel witnessed . . u utilization of loud music ....").

${ }^{21}$ Detainee 2600, supra note 17 (noting the use of change in temperatures).

${ }^{22}$ E-mail from [REDACTED] to Gary Bald et al., Fed. Bureau of Investigation (Dec. 5, 2003, 09:53 AM) [hereinafter Bald E-mail], available at http://www.aclu.org/torturefoia/released/FBI.121504.3977.pdf; see also Memorandum from Behavioral Analyst Unit, Fed. Bureau of Investigation, to Raymond S. Mey et al., Fed. Bureau of Investigation (May 30, 2003) [hereinafter BAU Memo], available at $\mathrm{http}: / /$ action.aclu.org/torturefoia/released/022306/1261.pdf.

$[\mathrm{S}]$ everal discussions were held to determine the most effective means of conducting interview of detainees: These discussions were prompted by the recognition that members of the Defense Intelligence Agency's (DIA) Defense Humint Services (DHS) were being encouraged at times to use aggressive interrogation tactics in GTMO which are of questionable effectiveness . . . . Not only are these tactics at odds with legally permissible interviewing techniques used by U.S. law enforcement agencies . . . but they are being employed by personnel in GTMO who appear to have little, if any, experience eliciting information for judicial purposes. The continued use of these techniques has the potential of negatively impacting future interviews by FBI agents as they attempt to gather intelligence and prepare cases for prosecution. 
From the beginning, FBI agents expressed concerns that Defense Department interrogation tactics produced unreliable and inadmissible intelligence. In their unsolicited complaints alone, the agents described thirteen incidents in which the Defense Department's interrogation techniques were likely to produce unreliable intelligence, four incidents in which the techniques were likely to be counterproductive, and three incidents in which the interrogation techniques were deemed likely to raise admissibility issues for the FBI. "In my weekly meetings with DOJ we often discussed [REDACTED] techniques and how they were not effective or producing intel that was reliable." ${ }^{23}$

\section{A. Impersonating the FBI}

One Defense Department interrogation technique of particular concern to the agents was the DOD interrogators' practice of posing as FBI agents during interrogations. Two agents expressed this concern. One stated the following:

We've heard that DHS [Department of Homeland Security] interrogators routinely identify themselves as FBI Agents and then interrogate a detainee for 16-18 hours using tactics as described above and others (wrapping in Israeli flag, constant loud music, cranking the $\mathrm{A} / \mathrm{C}$ down, etc). The next time a real Agent tries to talk to that guy, you can imagine the result. ${ }^{24}$

Another expressed similar sentiment: "If this detainee is ever released or his story made public in any way, DOD interrogators will not be held accountable because these torture techniques were done [by] the 'FBI' interrogators. The FBI will be left holding the bag before the public." ${ }^{25}$ Agents voiced concern with the DOD's practice of FBI agent impersonation in at least fourteen of their unsolicited complaints.

When FBI agents at Guantánamo expressed their objections to the treatment of detainees during interrogation, the complaints were met with indifference or blunt dismissal. For example, "We talked to him (Mr. [REDACTED]) several different times to let him know that we objected to the use of dogs and that we did not do business that

${ }^{23}$ E-mail from [REDACTED], Fed. Bureau of Investigation, to T.J. Harrington, Fed. Bureau of Investigation (May 10, 2004, 12:26 PM) (alteration in original), available at http:/ / www.aclu.org/files/projects/foiasearch/pdf/DOJFBI003085.pdf.

${ }^{24}$ Detainee 2600, supra note 17. The Schmidt Report addresses the impersonation issue; it states that FBI impersonations were discontinued because "[t]he technique, while authorized, was undermining the inter-agency working relationship." SCHMIDT REPORT, supra note 2, at 7.

${ }^{25}$ Bald E-mail, supra note 22. 
way. It was an inappropriate measure. He told us that we ([REDACTED] and I) 'were guests and we should act accordingly.'”26

The FBI agents' concerns were not limited to the practices of low-level DOD interrogators but, in fact, extended to some of the department's most senior officials. One agent, for example, cited the following specific concerns with the practices of Major General Geoffrey Miller:

From what cnn reports, gen karpinsky at Abu Gharib said that gen miller came to the prison several months ago and told her they wanted to "gitmotize" abu ghraib. I am not sure what this means. However, if this refers to intell gathering as I suspect, it suggests he has continued to support interrogation strategies we not only advised against, but questioned in terms of effectiveness. Yesterday, however, we were surprised to read an article in stars and stripers, in which gen miller is quoted as saying that he believes in the rapport-building approach. This is not what he was saying at gtmo when I was there. [REDACTED] and I did cart wheels. The battles fought in gitmo while gen miller he was there are on the record. ${ }^{27}$

General Miller was transferred to Iraq in the spring of 2004, and told the head of the military prison system that he was going to "Gitmoize" Iraq. ${ }^{28}$ The Abu Ghraib scandal broke thereafter. ${ }^{29}$

\footnotetext{
${ }^{26}$ See Schmidt-Furlow DeFerred, supra note 11, at 3770 (alteration in original) (emphasis added).

${ }^{27}$ E-mail from [REDACTED], to [REDACTED] (May 13, 2004, 3:42 PM) (emphasis added) (inconsistent capitalization and alterations in original), available at http://www1.umn.edu/humanrts/OathBetrayed/FBI\%204140.pdf; see also BAU Memo, supra note 22, at 4 .

The military and DHS's inaccurate portrayal to the Pentagon that the BAU had endorsed and, in fact, helped to create DHS's interrogation plan for [REDACTED] prompted SSA [REDACTED], SSA [REDACTED] and the FBI on-scene TDY operations supervisor, SSA [REDACTED] to send a letter (Encl 9) to MGEN Miller correcting these misstatements and requesting an opportunity to address the matter with MGEN Miller in person. During a subsequent meeting between MGEN Miller and SSAs [REDACTED] and SA [REDACTED] details and rationale for the BAU's interviewing approach were presented. Although MGEN Miller acknowledged positive aspects of this approach, it was apparent that he favored DHS's interrogation methods, despite FBI assertions that such methods could easily result in the elicitation of unreliable and legally inadmissible information.

Id. (alterations in original).

${ }^{28}$ Scott Wilson \& Sewell Chan, As Insurgency Grew, So Did Prison Abuse, WasH. Post, May 10, 2004, at A1. General Miller later did not recall using the word "Gitmoize." R. Jeffrey Smith \& Josh White, General Asserts She Was Overruled on Prison Moves, WASH. POST, May 12, 2004, at A1.
} 


\section{AFTER ABU GHRAIB}

Immediately after the Abu Ghraib abuses became public in 2004, the FBI sent an email to all agents stationed in Iraq requesting information regarding detainee abuses. FBI General Counsel Valerie E. Caproni later sent a modified version of this email to all agents who had ever been stationed at Guantánamo: "[Agents] who observed $a g$ gressive treatment... which was not consistent with Bureau interview policy/guidelines, should respond via email for the purpose of a followup [sic] interview." ${ }^{30}$

While many FBI agents responded to the formal solicitation, ${ }^{31}$ a majority of the unsolicited complaints previously raised between 2002 and 2004 do not appear to have been resubmitted. However, the complaints submitted by FBI agents in response to the formal July 2004 solicitation described many of the same types of interrogation techniques as did the agents' unsolicited complaints, including: isolation, ${ }^{32}$ hoodings, ${ }^{33}$ stress positions, ${ }^{34}$ sleep deprivation, ${ }^{35}$ and religious

29 Editorial, A System of Abuse, WASH. POST, May 5, 2004, at A28 ("The result of [Congress's] inaction and of the administration's refusal to respond to previous reports of abuses is the scandal of Abu Ghraib, which has done incalculable damage to the U.S. position in Iraq and around the world.").

${ }^{30}$ Fed. Bureau of InVEstigation, Detainees Positive Responses 3, 4 (2004) (emphasis added) [hereinafter POSITIVE RESPONSES], available at http://vault.fbi.gov/ Guantanamo\%20/Guantanamo\%20Part\%201\%20of\%201/view.

${ }^{31}$ Of the 532 FBI employees and contractors listed by the Counterterrorism Division as having served in Guantánamo during this time frame, only 434 submitted responses to the July 2004 solicitation. See id. Thus, almost twenty percent of those whose response were formally solicited did not respond.

${ }^{32}$ E.g., $i d$. at 258 (" $[\mathrm{O}]$ ne detainee was kept in the cell in isolation for an extended period of time, I think up to 30 days."); see also id. at 25 ("When [REDACTED] arrived in GTMO, number [REDACTED] was incarcerated in a darkened cell in the Naval Brig." (alterations in original)).

${ }^{33}$ E.g., $i d$. at 253 ("A detainee was led into an interview room by hooded MPs. The detainee was also hooded and the hood was removed by the MPs for the interview.").

${ }^{34}$ E.g., id. at 62 ("[D] uring the summer of 2002, [REDACTED] walked into a camp Delta observation room and noticed a detainee in an interview room . . . handcuffed with cuffs chained to his waist. [REDACTED] advised the chains were adjusted to force the detainee to stand in a 'baseball catcher' position." (alterations in original)).

${ }_{35}$ E.g., id. at 260-61.

During my assignment at GTMO I received a briefing from the military personnel assigned to operations at GTMO, the non-cooperative detainees could be placed on a list for a specific interrogation technique involving interruption of sleep pattern, called the "frequent flyer program." With this particular technique, identified detainees were moved frequently from cell block to cell block at intervals that appeared to be every hour or every two hours depending on the shifts and the availability of military personnel to move the detainee. Detai- 
and sexual imagery. ${ }^{36}$ One account, for instance, describes the forced baptism of a seventeen-year-old detainee: "Another interrogator ... bragged about making Detainee \#114 listen to satanic black metal music for hours and hours. Then the interrogator dressed as a Catholic Priest and baptized the detainee in order t[o] save him.." ${ }^{37}$ Many other complaints, such as the one that follows, describe the use of a combination of these and other techniques:

On a couple of occasions, I entered interview rooms to find a detainee chained hand and foot in a fetal position to the floor, with no chair, food, or water. Most times they had urinated or defacated [sic] on themselves, and had been left there for 18, 24 hours or more. On one occassion [sic], the air conditioning had been turned down so far and the temperature was so cold in the room, that the barefooted detainee was shaking with cold. When I asked the MP's [sic] what was going on, I was told that interrogators from the day prior had ordered this treatment, and the detainee was not to be moved. On another occassion [sic], the A/C had been turned off, making the temperature in the unventilated room probably well over 100 degrees. The detainee was almost

nees were moved along with all of their personal belongings. Due to the movement to different cells the detainees had their sleep interrupted throughout a 24 hour period.

Id.

I occasionally saw sleep deprivation interviews with strobe lights and two different kinds of loud music. I asked one of the interrogators what they were doing [and] they said that it would take approximately four days to break someone doing an interrogation 16 hours on with the lights and music and four hours off. The sleep deprivation and the lights and alternating beats of the music would wear the detainee down. There was a time period where the interrogations were obtrusive enough that the interview rooms for an entire trailer were not available if one of these techniques were being utilized. Id. at 44.

${ }^{36}$ E.g., $i d$. at 247-48 ("[D] etainees advised me that they had been subjected to loud music to keep them awake and had been shown pornographic photos in an effort to upset them. ... [T] [Tese were techniques used by Department of Defense (DOD) contract interviewers. This was common knowledge among FBI employees and it was a topic as I recall that was discussed at staff meetings because it was sometimes detrimental to our efforts of attempting to establish rapport with detainees."); see also id. at 188 ("At that time I saw another detainee sitting on the floor of the interview room with an Israeli flag draped around him, loud music being played and a strobe light flashing. I left the room immediately after seeing this activity.").

${ }^{37}$ SCHMIDT-Furlow DEFERRED, supra note 11, at 3758; see also POSITIVE RESPONSES, supra note 30, at 46. Yussef Mohammed Mubarak Al Shihri, ISN 114, was born on September 8, 1985. U.S. DeP'T OF DeF., List OF Individuals Detained By THE DEPARTMENT of Defense of GuANTANAMo BAy, Cuba From January 2002 through MAY 15, $2006 \quad$ (2006), available at http://www.dod.mil/pubs/foi/operation_and_plans/Detainee/detaineesFOIArelea se15May2006.pdf. 
unconscious on the floor, with a pile of hair next to him. He had apparently been literally pulling his own hair out throughout the night. On another occassion [sic], not only was the temperature unbearably hot, but extremely loud rap music was being played in the room, and had been since the day before, with the detainee chained hand and foot in the fetal position on the tile floor. ${ }^{38}$

Some of the agents' accounts, such as the one that follows, alleged that detainees were denied food and water:

Sometime in the second or third week of February of 2004, [REDACTED] was taken to reservation. ([REDACTED] was on both FBI and NAE hold.) He ... was yelled at for 25 minutes, [REDACTED] was short-shackled, the room temperature was significantly lowered, strobe lights were used, and possibly loud music.... After the initial 25 minutes of yelling, [REDACTED] was left alone in the room in this condition for approximately 12 hours... . During the 12 hours, [REDACTED] was not permitted to eat, pray, or use the bathroom.

Other accounts described harmful physical conduct:

When the detainee was brought in for the interview, [REDACTED] observed the detainee had a black eye, facial cuts around the nose area, and his fingers on both hands were taped up. The detainee, who spoke English, said words to the effect [of] "they," motioning to the Military Police (MP) guards, had done this to him. A Colonel in charge of the MPs, whose name [REDACTED] could not recall, advised that the detainee's injuries were sustained in a scuffle due to the detainee becoming noncompliant and had to be brought into compliance by a Rapid Response Team. ${ }^{40}$

Still another complaint described how one physically ill detainee vomited repeatedly during his fifteen-hour long interrogation:

[REDACTED] was being debriefed for several hours (approximately 15 hours) by NAE [the DOD's North Africa-Europe team]. Throughout the session, [REDACTED] periodically threw up in a trash can. At the time, I was told he had an ulcer and that the stress was irritating it. I was later advised he had a stomach vi-

38 Positive ReSPONSES, supra note 30 , at 10.

39 Id. at 214 (alterations in original); see also id. at 12.

("On a couple of occasions, I entered interview rooms to find a detainee chained hand and foot in a fetal position to the floor, with no chair, food, or water. Most times they had urinated or defecated on themselves, and had been left there for 18 , 24 hours or more. On one occasion. . . . I was told that interrogators from the day prior had ordered this treatment, and the detainee was not to be moved.").

${ }^{40} I d$. at 82 (alterations in original). 
rus. I was told he had been given a shot of Motrin (or something like that) by the medical staff.

While the agents' solicited complaints are very similar in content to their unsolicited complaints, there are fewer references to general abuse / torture among the complaints that were formally solicited by the FBI. One possible explanation for this is that the formal solicitation (whether intentionally or inadvertently) limited the scope of agents' responses. One agent, for instance, submitted the following query upon receiving the formal solicitation: "I observed what may have been aggressive techniques used by non-FBI interrogators. Does this still fall into what you are looking into?" ${ }^{42}$ The agent's confusion highlights the solicitation's ambiguity, and it is difficult to estimate what information may have been withheld as a result.

The FBI agents reported that their ability to observe the DOD interrogation techniques was limited. For example, agents reported that although there were eight interrogation rooms in each trailer, two of the eight were off limits to the FBI agents. ${ }^{43}$ The agents also reported that sometimes entire trailers were off limits to FBI agents during interrogation. For instance, one agent stated that "[o]ften DOD personnel would reserve an entire trailer when employing aggressive interview techniques ...." ${ }^{44}$ The FBI investigation into the agents' formally solicited reports began on July 9, 2004, and was completed on September 23, 2004 . $^{45}$

\section{WhAT SENIOR DEFENSE DEPARTMENT OfFICIALS KNEW}

There is some confusion as to when the FBI first formally alerted the DOD to reported misconduct toward the detainees by DOD Interrogators. On July 14, 2004, FBI Deputy Director T.J. Harrington sent a partial disclosure of the reported abuses to Major General Donald J. Ryder (then Provost Marshall of the Army). ${ }^{46}$ The document described and attached two separate complaints, which were initially reported in 2002 by FBI agents in Guantánamo to the FBI Headquarters in Washington D.C. ${ }^{47}$ It is possible that the reports were sent at

${ }^{41} I d$. at 214-15 (first and third alterations in original).

${ }^{42} \quad I d$. at 68 .

${ }^{43}$ Id. at 44-49; see also Testimonies of FBI Agents, CTR. FOR STUdy Hum. RTS. Ams., http:/ / humanrights.ucdavis.edu/projects/the-guantanamo-testimonialsproject/testimonies/testimonies-of-fbi-agents/index (last visited Sept. 29, 2011).

${ }^{44}$ Positive ResPonses, supra note 30, at 45.

45 See generally FOIA Documents, supra note 4.

${ }^{46}$ Harrington Letter, supra note 1.

${ }^{47}$ See id. 
the time they were made; if so, no action was taken on them, thus leading to the July $14^{\text {th }}$ report. It is also possible that the FBI withheld this information for almost two years. In any event, each of the complaints in the email to Major General Ryder alleges serious mistreatment of detainees.

The first of these complaints describes an instance in which a DOD interrogator inflicted physical pain upon a detainee's hands and genitals while the detainee was shackled to the floor and unable to protect himself:

During late 2002, FBI Special Agent [REDACTED] was present in an observation room at GTMO and observed [REDACTED] (first name unknown) [REDACTED] conducting an interrogation of an unknown detainee. (SA [REDACTED] was present to observe the interrogation occurring in a different interrogation room). [REDACTED] entered the observation room and complained that curtain movement at the observation window was distracting the detainee, although no movement of the curtain had occurred. She directed a marine to duct tape a curtain over the two-way mirror between the interrogation room and the observation room. SA [REDACTED] characterized this action as an attempt to prohibit those in the observation room from witnessing her interaction with the detainee. Through the surveillance camera monitor, SA [REDACTED] then observed [REDACTED] position herself between the detainee and the surveillance camera. The detainee was shackled and his hands were cuffed to his waist. SA [REDACTED] observed [REDACTED] apparently whispering in the detainee's ear, and caressing and applying lotion to his arms (this was during Ramadan when physical contact with a woman would have been particularly offensive to a Moslem male). On more than one occasion the detainee appeared to be grimacing in pain, and [REDACTED]'s hands appeared to be making some contact with the detainee. Although SA [REDACTED] could not see her hands at all times, he saw them moving towards the detainee's lap. He also observed the detainee pulling away and against the restraints. Subsequently, the marine who had previously taped the curtain and had been in the interrogation room with [REDACTED] during the interrogation re-entered the observation room. SA [REDACTED] asked what had happened to cause the detainee to grimace in pain. The marine said [REDACTED] had grabbed the detainee's thumbs and bent them backwards and indicated that she also grabbed his genitals. The marine also implied that her treatment of that detainee was less harsh than her treatment of others by indicating that he had seen her treatment 
of other detainees result in detainees curling into a fetal position on the floor and crying in pain. ${ }^{48}$

The second complaint contained in General Ryder's e-mail details an incident in which a detainee's mouth was duct-taped for chanting the Koran while an amused military employee who applied the duct tape watched.

These FBI complaints appear to be the only unsolicited complaints that the FBI ever forwarded to the DOD. On December 15, 2004, the FBI made a formal submission to DOD of all of the responses that the FBI agents had made to the FBI solicitation of July 9, $2004 .^{50}$ The FBI submission of December $15^{\text {th }}$ did not include any of the unsolicited complaints sent by the FBI agents stationed in Guantánamo while they were actually at Guantánamo.

There is no evidence that either the FBI or the Defense Department did anything with the remainder of the unsolicited complaints.

${ }^{48} I d$. (alterations in original). Although the Schmidt Enclosures contains a description of a similar incident, see ENCLOSURES, supra note 4, at 842, this event is never addressed in the Schmidt Report.

${ }^{49}$ Harrington Letter, supra note 1 . This incident is likely one and the same as a similarly described event that appears in the Report. See Schmidt Report, supra note 2, at 11-12; see also SCHMIDT-FURLOW DEFERRED, supra note 11, at 3761.

Agent [REDACTED] and I were watching an FBI interrogation in one of the interrogation trailers when [REDACTED] came into the observation booth. He was excited and stated that he had something to show us. I was curious, so I followed [REDACTED] down the hallway to an interrogation room. When I arrived at the interrogation room, I observed six or seven soldiers (or persons I believed were soldiers) laughing and pointing at something inside the room. When I looked inside the room I noticed a detainee with his entire head covered in duct tape (except for his eyes and maybe mouth). I asked [REDACTED] why the detainee's head was covered with duct tape? [REDACTED] stated because he (the detainee) refused to stop "chanting the Koran" during an interrogation session. When I asked [REDACTED] how he planned to take the tape off without hurting the detainee (the detainee had a beard and longer hair), [REDACTED] just laughed. I immediately informed Agent [REDACTED] and proceeded to notify the Criminal Investigation task Force attorney (either [REDACTED] I don't think [REDACTED] personally put the duct tape on the detainee's head, but I believe from his actions he directed the soldiers to do it.

Id. (alterations in original).

${ }^{50}$ SCHMIDT REPORT, supra note 2, at 1-3. 


\section{THE SCHMIDT REPORT AND ITS LIMITATIONS}

\section{A. General Schmidt's Report}

Confronted with the FBI's solicited complaints, the DOD directed Lieutenant General Randall M. Schmidt to initiate an investigation and draft a response. ${ }^{51}$ General Schmidt's quite limited task was to determine whether an enumerated list of types of conduct described in the formally solicited complaints were authorized at any time by the Army Field Manual. ${ }^{52}$ The scope of General Schmidt's investigation was substantially limited by an explicit instruction to ignore any "allegations that are the subject of ongoing criminal investigations by the Army Criminal Investigation Division." ${ }^{53}$ These investigations were not public. ${ }^{54}$ The Army released the results of a small number of closed investigations, including one that describes how a detainee was repeatedly thrown to the floor during an interrogation. ${ }^{55}$ The Schmidt Report, however, does not mention that a detainee was ever thrown to the floor despite the fact that the solicited responses included a description of such an incident. ${ }^{56}$

The resulting report, Investigation into FBI Allegations of Detainee Abuse at Guantánamo Bay, Cuba Detention Facility, asserted that there was "no evidence" that "torture or inhumane treatment" occurred at Guantánamo, and, further, that only three instances occurred in which interrogation acts were "in violation of interrogation techniques authorized by Army Field Manual 34-52 and [DOD] guidance. $^{, 57}$ The Schmidt Report stated that sufficient evidence did not

${ }^{51} I d$. at 2-3. The Defense Department originally assigned this task to Brigadier General John T. Furlow, but General Schmidt eventually assumed responsibility for the investigation and authored the resulting report. Id.

${ }^{52}$ Id. at 3-4 (emphasis added).

${ }^{53}$ Craddock Memo, supra note 9, in ENCLOSURES, supra note 4 ("You are not to investigate allegations that are the subject of ongoing criminal investigations by the Army Criminal Investigative Division.").

${ }^{54}$ Frequently Asked Questions, U.S. ARMY CRIM. InVESTIGATION COMMAND, http://www.cid.army.mil/faqs.html (last visited Sept. 29, 2011) ("As a matter of policy, CID does not confirm when someone is the subject or suspect of an ongoing criminal investigation due to the person's Constitutional due process and Privacy Act rights.").

${ }_{55}$ See Memorandum from [REDACTED], to [REDACTED] (Apr. 25, 2003) (on file with author).

${ }^{56}$ Positive Responses, supra note 30, 71-72.

${ }^{57}$ SCHMidt REPORT, supra note 2, at 1; see also Kathleen Rhem, Alleged Guantanamo Abuse Did Not Rise to Level of 'Inhumane,' U.S. DEP'T DEF. (July 13, 2005), http://www.defense.gov/news/newsarticle.aspx?id=16651 ("'I do not, however, consider this treatment to have crossed the threshold of being inhumane,' Air Force Lt. 
exist to support agents' accounts that an interrogator groped a detainee's genitals or that a detainee pulled his own hair out due to the heat.

The DOD voluntarily released the Schmidt Report, which the Defense Department represented as a complete review of allegations of mistreatment and abuse at Guantánamo Bay. ${ }^{59}$ The Report has since been cited by the Defense Department and members of the Senate Armed Services Committee in support of the proposition that no detainee abuse occurred at Guantánamo.

Gen. Randall Schmidt, the senior investigating officer, told members of Senate Armed Services Committee.”).

58 SCHMIDT REPORT, supra note 2, at 12, 22-23.

59 See Rhem, supra note 57.

${ }^{60} I d$. The DOD stated that: Schmidt's report constitutes the $12^{\text {th }}$ major review of detainee operations. In today's hearing, Virginia Sen. John Warner noted that the few cases of misconduct cited in the report should be viewed in the context of roughly 24,000 interrogations conducted at Guantánamo Bay since detention operations began there in early 2003.

Id.

Before his publicized exit from the position of Deputy Assistant Secretary for Detainee Affairs Cully Stimson explained the following position in a January 10, 2007, interview on C-SPAN:

Caller: Hello, I am Andrew from Paramus. I guess what is disconcerting of Mr. Stimson, is how he brushes aside any concerns of Guantánamo and its impact on our foreign policy and the image of the United States. And that is what is concerning to me. What I would like is specifically for him to address the FBI agents who have gone to Guantánamo. Saw what was going on there, refused to participate in interrogations because of the abuses they saw, and the abuses they continued to see. These aren't ACLU types, these are FBI agents and I have never heard the administration clearly address those concerns. Thank you. Cully Stimson: Um, the administration has addressed those concerns. In fact you can go to the DOD website, and read the Schmidt Furlow report. There are no abuses going on now. In the beginning of Guantánamo, we have been very candid with the public, there were incidents, minor, where people mistreated detainees. Those incidents were investigated. People were held accountable. The FBI agents are not seeing abuses at Guantánamo now. The Washington Post article later, or last week, was somewhat disingenuous in my opinion. . . . In 2002, in 2003, a FBI agent witnessed interrogation techniques that he was unfamiliar with as a law enforcement officer. He emailed headquarters, headquarters didn't respond, but what happened is, the military took it upon itself to investigate those emails, and General Schmidt and General Furlow issued a report that is open for the world to see. It was issued about 2 years ago looking into those allegations. Some were found to be true, most were not found to be true. But you can read it for yourself.

Interview with Cully Stimson (C-SPAN television broadcast Jan. 10, 2007) (emphasis added), available at http://www.c-spanvideo.org/program/BayDetaine. 


\section{B. Omitted from the Schmidt Report}

The Schmidt Report omitted reference to nearly all of the unsolicited reports of mistreatment of prisoners, presumably because the FBI did not make those reports available to the DOD. In addition, the Schmidt Report failed to address even some of the solicited FBI complaints-those that General Schmidt was specifically tasked to review. Since nothing was publicly known of the FBI's complaints of detainee mistreatment until the Schmidt Report's publication, however, it was impossible to know what was missing from the report until the ACLU's FOIA litigation triggered the production of the actual FBI complaints.

The Schmidt Report neither evaluates nor references many of the FBI reports that had been forwarded to the Defense Department on December 15, 2004. Specifically, those FBI reports contain at least five reports of physical beatings, which the Schmidt Report does not address. For instance, the Schmidt Report makes no mention of the following account, which was part of the December 15, 2004, referral:

When the detainee was brought in for the interview, [REDACTED] observed the detainee had a black eye, facial cuts around the nose area, and his fingers on both hands were taped up. The detainee, who spoke English, said words to the effect of "they," motioning to the Military Police (MP) guards, had done this to him. A Colonel in charge of the MPs, whose name [REDACTED] could not recall, advised that the detainee's injuries were sustained in a scuffle due to the detainee's becoming non-compliant and had to be brought into compliance by a Rapid Response Team. ${ }^{61}$

There is a handwritten note on this FBI report (presumably written by the FBI official who evaluated the report), which reads: "Why would it be necessary/reasonable to break fingers?" ${ }^{22}$

The Schmidt Report also makes no mention of the following incident, in which a detainee was shown pornography:

[D] etainees advised me that they had been subjected to loud music to keep them awake and had been shown pornographic photos in an effort to upset them.... these were techniques used by Department of Defense (DOD) contract interviewers. This was common knowledge among FBI employees and it was a topic as I recall that was discussed at staff meetings because it was some-

${ }^{61}$ Positive Responses, supra note 30 , at 82 (alterations in original).

${ }^{62} I d$. at 81. 
times detrimental to our efforts of attempting to establish rapport with detainees. ${ }^{63}$

Additionally, the Schmidt Report fails to address at least four instances of religious abuse, including the following incident, which was perpetrated upon a teenaged detainee: "Another interrogator (not sure if military or contractor or other) bragged about making Detainee \# [REDACTED] listen to satanic black metal music for hours and hours. Then the interrogator dressed as a Catholic Priest and baptized the detainee in order to save him."

Since General Schmidt was instructed to investigate only certain types of abuse, and since he was specifically forbidden to address any conduct which was currently under criminal investigation, it may not be surprising that the Schmidt Report does not address many instances of abuse that FBI agents and others reported. This might explain why the Schmidt Report does not mention, for instance, an incident in which an interrogator "went across the desk" at a detainee. It is impossible to know which of the reported incidents were "off limits" for General Schmidt's investigation insofar as they were the subject of criminal inquiry because no public disclosure of criminal inquiries-let alone indictments-has been made as to any of the complaints. Even if General Schmidt were conscientious within the parameters of his instructions, it is clear that his resulting report cannot establish what the report is sometimes said to prove: the absence of abuse at Guantánamo.

There are, however, reasons to doubt the accuracy of the Schmidt Report even within its own highly restricted confines.

\section{Buried Complaints: The Schmidt "Enclosures"}

In the course of his investigation into the reports referred by the FBI on December 15, 2004, General Schmidt discovered additional evidence of improper Defense Department interrogation techniques. The additional detainee abuses discovered by General Schmidt included the use of dogs, denial of food and water, beatings, threats, isolation, disorientation, and at least fifteen incidents of sexual

${ }^{63} I d$. at 247-48 (alterations in original).

${ }^{64}$ Id. at 44; see also id. at 188 ("At that time I saw another detainee sitting on the floor of the interview room with an Israeli flag draped around him, loud music being played and a strobe light flashing. I left the room immediately after seeing this activity.").

${ }^{65}$ SChMidT-Furlow DeFERRED, supra note 11, at 3744 ("We physically removed an FBI agent when he went across the desk at a detainee.”). 
abuse. ${ }^{66}$ Yet, General Schmidt did not mention in his published report any of these additional incidents-uncovered by his own investigation-of detainee mistreatment at the hands of the Defense Department.

Instead, General Schmidt collected these other reports of abuses and placed them in a separate file, which he denominated as "Enclosures" and relegated to a separate appendix. ${ }^{67}$ The appendix was then excluded from the actual published report, as was any reference to the appendix, the "Enclosures" or the underlying abuses themselves. Therefore, these additional reports of abuses were unknown and unknowable from the published record, and would have remained hidden but for the FOIA litigation, which ultimately required their production.

General Schmidt not only relegated these findings to an unpublished appendix, but he also failed to mention them in his testimony before Congress. $^{68}$ Thus, burying these reports in the unpublished appendix meant that neither Congress nor the public was aware that General Schmidt and Brigadier General John T. Furlow knew of the seventy-nine instances of abuse described in the "Enclosures"including the use of dogs, denial of food and water, beatings, threats, isolation, disorientation, and at least fifteen incidents of sexual abuse.

Although the "Enclosures," along with both the solicited and unsolicited FBI complaints, generally establish that the use of objectionable interrogation techniques by the Defense Department was widespread, the Schmidt Report concludes just the opposite-ultimately declaring that there was "no evidence of torture or inhumane treatment" at Guantánamo. ${ }^{69}$

Given that the findings in the "Enclosures" resulted from General Schmidt's own investigation, not only was his testimony to Congress, that no inhumane treatment occurred at Guantánamo, inaccurate, but there was also a reason to question his motivation for making a statement so greatly at variance with his own investigation.

\section{CONCLUSION}

Although FBI agents described hundreds of instances of improper conduct by DOD interrogators at Guantánamo Bay, and senior

${ }^{66}$ See ENCLOSURES, supra note 4.

${ }^{67}$ ENCLOSURES, supra note 4.

68 See Hearing on Guantanamo Bay Detainee Treatment before the S. Armed Servs. Comm., 108th Cong. (2005) (statement of Lieutenant Gen., U.S. Air Force, Randall Schmidt).

${ }^{69}$ SCHMIDT REPORT, supra note 2, at 1 . 
FBI officials were privy to such reports as early as 2002, the FBI did not confront the DOD with the agents' complaints until more than two years later, in 2004. Even then, the FBI provided the department with less than half of those complaints. In response, the Defense Department produced a staggeringly incomplete and therefore inaccurate report-upon which Congress has relied-that summarily concludes that there was "no evidence of torture or inhumane treatment at Guantánamo." 